\title{
Syrian refugees in seasonal agricultural work: a case of adverse incorporation in Turkey
}

\section{Sinem Kavak}

Doi: $10.1017 /$ npt.2016.7. Published online on August $3^{\text {rd }} 2016$.

In New Perspectives on Turkey's issue no. 54, in the article entitled "Syrian refugees in seasonal agricultural work: a case of adverse incorporation in Turkey" by Sinem Kavak, the author wishes to have the following corrigendum published.

Additional footnote:

On pages 40 to 44 , where the overall conditions of the seasonal agricultural workers are discussed, the data presented was drawn from a research project with a broader scope on seasonal migrant work in agriculture. The results were published in a co-authored report by Pınar Uyan Semerci, Emre Erdoğan, and Sinem Kavak entitled Mevsimlik Gezici Tarım İşçiliği Raporu (Hayata Destek İnsani Yardım Derneği, 2014). Figures 1 to 7 are consecutively taken from the pages $23,26,57,91,45,66$ and 65 of the mentioned research report.

I apologize from the co-authors and readers for not providing this footnote in the previous issue of NPT.

\section{Reference}

Kavak, Sinem. "Syrian refugees in seasonal agricultural work: a case of adverse incorporation in Turkey." New Perspectives on Turkey 54 (2016): 33-53. 